\title{
Transvaginal retropubic sling systems: efficacy and patient acceptability
}

\author{
This article was published in the following Dove Press journal: \\ International Journal of Women's Health \\ 16 February 2015 \\ Number of times this article has been viewed
}

\author{
Christina P Moldovan' \\ Michelle E Marinone ${ }^{2}$ \\ Andrea Staack ${ }^{3}$ \\ 'Department of Psychology, Loma \\ Linda University, Loma Linda, \\ California, United States of \\ America; ${ }^{2}$ School of Medicine, \\ Loma Linda University, Loma Linda, \\ California, United States of America; \\ ${ }^{3}$ Department of Urology, Loma Linda \\ University Medical Center, Loma \\ Linda, California, United States \\ of America
}

\begin{abstract}
Stress urinary incontinence is a common, disabling, and costly medical problem that affects approximately $50 \%$ of women with urinary incontinence. Suburethral retropubic slings have been developed as a minimally invasive and effective surgical option, and they have been used as a first-line treatment for stress urinary incontinence since 1995 . However, complications including vaginal extrusion, erosion, pain, bleeding, infections, lower urinary tract symptoms, urinary retention, and incontinence have been reported with use of the slings. Several companies manufacture sling kits, and the sling kits vary with regard to the composition of the mesh and introducer needle. The aim of this review was to determine which sling kit was most effective for patients, had minimal reported side effects, and was best accepted by patients and surgeons. In a review of the literature, it was found that a total of 38 studies were published between 1995 and 2014 that reported on eight tension-free retropubic sling kits: SPARC, RetroArc, Align, Advantage, Lynx, Desara, Supris, and Gynecare TVT. The Gynecare TVT was the most cited sling kit; the second most cited was the SPARC. This review provides a summary of the studies that have examined positive and negative outcomes of the retropubic tension-free suburethral sling procedure using various sling kits. Overall, the results of the literature review indicated that data from comparisons of the available sling kits are insufficient to make an evidenced-based recommendation. Therefore, the decision regarding which sling kit is appropriate to use in surgery is determined by the medical provider's preference, training, and past experience, and not by the patient.
\end{abstract}

Keywords: stress urinary incontinence, retropubic sling kits, efficacy, outcome

\section{Introduction}

Urinary incontinence (UI), defined as the involuntary leakage of urine, is a universal medical problem that may significantly impact an individual's quality of life. ${ }^{1}$ A diagnosis of UI has been associated with an increase in anxiety and depression and a decrease in social and emotional health. ${ }^{2}$ In addition, the economic expenses associated with UI, such as the cost of laundry, pads, medications, reduced workplace productivity, and other health care-related costs can have a significant toll on an individual's financial status. ${ }^{1}$

Stress urinary incontinence (SUI) occurs when an increase in intra-abdominal pressure exceeds urethral closure pressure and thus results in an involuntary leakage of urine. This may occur with physical exertion, such as sneezing, coughing, or exercising. ${ }^{3}$ It is difficult to obtain an accurate estimate of the prevalence of incontinence because the phenomenon has been examined by using a variety of definitions, populations, ages, and measuring instruments. ${ }^{4}$ However, research shows that SUI accounts for approximately $50 \%$ of incontinence occurrences. ${ }^{5}$
Correspondence: Andrea Staack University Medical Center, II 370 Anderson Street, Suite I I00, Loma Linda, California 92354, United States of America

Tel + I 9095582830

Fax + I 9095582445

Email astaack@llu.edu submit your manuscript | www.dovepress.com

Dovepress

http://dx.doi.org/10.2147/IJWH.S59265
International Journal of Women's Health 2015:7 227-237 
Treatment options for SUI may consist of pelvic floor muscle training, pharmaceuticals, weight loss interventions, topical estrogen therapy, ${ }^{6}$ and surgery (such as urethropexy, ${ }^{7}$ needle-assisted bladder neck suspension, ${ }^{8}$ and colposuspension) is the ultimate treatment for SUI. ${ }^{6}$ In 1995, Ulmsten et al ${ }^{9}$ invented the tension-free vaginal tape procedure (TVT), which has become the gold standard for the surgical treatment of SUI, by utilizing a suburethral retropubic sling made out of mesh. All of the surgical procedures have similar reported treatment outcomes; however, the tension-free suburethral sling placement has been shown to be simpler, less costly, and shorter in duration than the other procedures. ${ }^{6}$ Surgery offers a long-term solution for SUI by restoring the normal urethral support and urethral closure pressure to maintain continence during intra-abdominal pressure increases. ${ }^{3}$

The tension-free suburethral sling operations vary by the placement of the sling arms towards either the retropubic or the transobturator space and by the sling material used. The two main types of suburethral tapes are the TVT and the transobturator tape (TOT).${ }^{10}$ Both sling types are placed suburethrally and, with respect to the urethra, distally, midurethrally, or proximally. During the TVT procedure, the sling is placed through the retropubic space by using small suprapubic and vaginal incisions. ${ }^{10}$ Shortly after the acceptance of the TVT, other approaches were developed in order to decrease some of the complications, such as bladder perforation and vascular injury, that were related to needles passing through the retropubic space. ${ }^{10}$ One of the more recent procedures includes the TOT, in which the sling is placed toward the obturator foramen lateral to the inferior pubic ramus; this procedure has been shown to have a lower risk of bladder and vascular injury but is associated with more groin pain. ${ }^{10}$ Additional procedures, including the mini- and single-incision slings, still need to be assessed in comparative clinical trials. ${ }^{6}$ Despite the additional techniques now available, the retropubic tension-free suburethral sling procedure continues to be widely used today, and it is considered the preferred first-line of treatment for SUI in women. ${ }^{6}$

Ethicon, a subsidiary of Johnson \& Johnson, was the first manufacturer to produce a retropubic surgical sling kit, named the Gynecare TVT (Sommerville, NJ, USA). The kit includes a synthetic mesh sling in a plastic sheath and two introducer needles with handles. Other manufacturers have created their own variations of the retropubic sling system (see Table 1 for eight currently available brands). Although each manufacturer has created its own kit, the products and the surgical procedure used to insert them vary only slightly, and it may be difficult for surgeons to choose one brand over another.
As previously stated, suburethral sling procedures differ with regard to the type and structure of the implant as well as the length and composition of the handle for advancing the introducer needles. Mesh material is classified into four different categories: ${ }^{11}$

1. Type I consists of macroporous mesh (eg, Prolene). The pore size is $>75 \mu \mathrm{m}$ and hence allows infiltration by macrophages, fibroblasts, blood vessels in angiogenesis, and collagen fibers.

2. Type II consists of microporous mesh (eg, Gore-Tex) and has a smaller pore size of $<10 \mu \mathrm{m}$.

3. Type III consists of a macroporous patch with multifilaments or a microporous component (eg, woven Dacron, polypropylene).

4. Type IV consists of submicronic pores (eg, Silastic, dura mater substitute).

Most of the commercially available tension-free suburethral slings use Type I mesh. ${ }^{12}$

Researchers suggest that the type of mesh used for slings may impact treatment outcomes and complications. ${ }^{13}$ Lowdensity monofilament polypropylene meshes are desirable because they are less susceptible to degradation and hence reduce adverse effects such as infection and inflammation. ${ }^{14}$ Each type of mesh interacts differently with the immune system and provides a unique local tissue response. ${ }^{15}$ The biomechanical properties of many existing slings have not been defined. Of the slings that have been examined in the literature, the Gynecare TVT, SPARC (American Medical Systems, Inc., Minnetonka, MN, USA), and Advantage (Boston Scientific, Marlborough, MA, USA) are made of monofilament polypropylene. However, the slings vary with regard to the knitting pattern and pore size..$^{13} \mathrm{~A}$ comparison of the slings revealed that the Gynecare TVT uses a Type I monofilament, macroporous mesh that has been shown to have a unique tensile behavior of low stiffness and easy elongation, a combination which appears to reduce postoperative complications. ${ }^{13}$ The SPARC and the Advantage have similar textile properties, but are slightly inferior in terms of the stretch and durability of the material. Further research is needed to examine textile properties of the mesh material in other currently used retropubic slings, such as the Align (Bard Medical, Covington, GA, USA), the Lynx (Boston Scientific, Marlborough, MA, USA), and the Desara (Caldera Medical, Inc., Agoura Hills, CA, USA).

To the best of the authors' knowledge, no review article has offered a synthesis of comparative studies featuring the presently available retropubic sling systems. Therefore, this review describes the different sling kits currently 
Table I Available retropubic sling kits

\begin{tabular}{|c|c|c|c|c|}
\hline Kit & Material classification & $\begin{array}{l}\text { FDA } 5 \text { I } 0(k) \text { premarket } \\
\text { notification* date }\end{array}$ & References & $\begin{array}{l}\text { Number of patients } \\
\text { per reference }\end{array}$ \\
\hline $\begin{array}{l}\text { RetroArc (American } \\
\text { Medical Systems) }\end{array}$ & $\begin{array}{l}\text { Type I, knitted macroporous, } \\
\text { monofilament polypropylene mesh }\end{array}$ & November 20, 2013 & N/A & \\
\hline SPARC (American & Type I, knitted macroporous, & August I, 200I & Andonian et $\mathrm{a}^{25}$ & 84 \\
\hline \multirow[t]{10}{*}{ Medical Systems) } & monofilament polypropylene mesh & & Deval et $\mathrm{a}^{45}$ & 104 \\
\hline & & & Dietz et $\mathrm{a}^{24}$ & 106 \\
\hline & & & Heidler et $\mathrm{a}^{47}$ & 46 \\
\hline & & & Hodroff et al ${ }^{49}$ & 445 \\
\hline & & & Kobashi and Govier ${ }^{50}$ & 150 \\
\hline & & & Lord et $\mathrm{a}^{26}$ & 301 \\
\hline & & & Paick et $\mathrm{a}^{28}$ & 94 \\
\hline & & & Primus ${ }^{48}$ & 103 \\
\hline & & & Siddiqui et $\mathrm{a}^{46}$ & 100 \\
\hline & & & Tseng et $\mathrm{a}^{27}$ & 62 \\
\hline Align (Bard) & $\begin{array}{l}\text { Type I, knitted macroporous, } \\
\text { monofilament polypropylene mesh }\end{array}$ & March 2I, 2007 & Kawasaki et $\mathrm{al}^{21}$ & 28 \\
\hline Advantage (Boston & Type I, knitted macroporous, & $\mathrm{N} / \mathrm{A}$ & Basu and Duckett ${ }^{52}$ & 33 \\
\hline \multirow[t]{2}{*}{ Scientific) } & monofilament polypropylene mesh & & Lim et $\mathrm{al}^{22}$ & 664 \\
\hline & & & Renganathan et $\mathrm{al}^{51}$ & 70 \\
\hline \multirow[t]{2}{*}{ Lynx (Boston Scientific) } & Type I, knitted macroporous, & $\mathrm{N} / \mathrm{A}$ & Agarwala and Griffin ${ }^{23}$ & 83 \\
\hline & monofilament polypropylene mesh & & Noblett et al ${ }^{53}$ & 102 \\
\hline Desara (Caldera) & $\begin{array}{l}\text { Type I, knitted macroporous, } \\
\text { monofilament polypropylene mesh }\end{array}$ & May 8, 2008 & N/A & \\
\hline Supris (Coloplast) & $\begin{array}{l}\text { Type I, knitted, macroporous, } \\
\text { monofilament polypropylene mesh }\end{array}$ & June 24,2011 & $\mathrm{~N} / \mathrm{A}$ & \\
\hline \multirow[t]{29}{*}{ Gynecare TVT (Ethicon) } & Type I, knitted, macroporous, & October 26, 201I & Abouassaly et a ${ }^{59}$ & 241 \\
\hline & monofilament polypropylene mesh & & Agarwala and Griffin ${ }^{23}$ & 83 \\
\hline & & & Andonian et $\mathrm{a}^{25}$ & 84 \\
\hline & & & Dietz et $\mathrm{al}^{24}$ & 106 \\
\hline & & & Hong et $\mathrm{al}^{42}$ & 375 \\
\hline & & & Karram et $\mathrm{al}^{58}$ & 350 \\
\hline & & & Kawasaki et $\mathrm{a}^{21}$ & 28 \\
\hline & & & Klutke et $\mathrm{al}^{39}$ & 598 \\
\hline & & & Kuuva and Nilsson ${ }^{32}$ & 1,455 \\
\hline & & & Levin et $\mathrm{a}^{33}$ & $24 I$ \\
\hline & & & Lim et $\mathrm{a}^{22}$ & 664 \\
\hline & & & Lord et $\mathrm{al}^{26}$ & 301 \\
\hline & & & Meschia et $\mathrm{al}^{30}$ & 404 \\
\hline & & & Nilsson et $\mathrm{a}^{34}$ & 80 \\
\hline & & & Nilsson et $\mathrm{a}^{35}$ & 101 \\
\hline & & & Nilsson et $\mathrm{al}^{37}$ & 85 \\
\hline & & & Nilsson et $\mathrm{al}^{41}$ & 69 \\
\hline & & & Olsson and Kroon ${ }^{38}$ & 51 \\
\hline & & & Paick et a ${ }^{28}$ & 94 \\
\hline & & & Paick et al ${ }^{44}$ & 274 \\
\hline & & & Rezapour and Ulmsten ${ }^{36}$ & 34 \\
\hline & & & Shippey et $\mathrm{al}^{56}$ & 109 \\
\hline & & & Tamussino et $\mathrm{a}^{31}$ & 2,795 \\
\hline & & & Tincello et $\mathrm{al}^{29}$ & 437 \\
\hline & & & Tseng et $\mathrm{a}^{27}$ & 62 \\
\hline & & & Tsivian et a ${ }^{43}$ & 55 \\
\hline & & & Tsivian et $a^{\mid 61}$ & 200 \\
\hline & & & Ulmsten et $\mathrm{al}^{40}$ & 50 \\
\hline & & & Wang ${ }^{60}$ & 600 \\
\hline
\end{tabular}

Notes: *FDA $510(\mathrm{k})$ Premarket Notification is a premarketing submission made to the FDA to demonstrate that the device to be marketed is as safe and effective as (or substantially equivalent to) a legally marketed device that is not subject to premarket approval. Premarket notification (5IO[k]) to FDA is required at least 90 days before marketing unless the device is exempt from $510(\mathrm{k})$ requirements.

Abbreviations: FDA, US Food and Drug Administration; N/A, not available. 
being used by health care providers. An effort is made to compare the efficacy and patient acceptability of each kit, and the difficulties encountered in such comparisons are discussed. The current review addresses five questions: 1) How acceptable are sling kits in light of the controversy regarding their safety? 2) Which sling kits are currently being used in practice? 3) Of the available sling kits, which one is being used the most among surgeons? 4) Which sling kits have the most significant side effects? and 5) Which sling kits provide the best treatment outcomes? Because the previous research in these areas is limited, these questions are exploratory.

\section{Method}

\section{Procedure}

A general web search using the term 'retropubic sling systems' was conducted to identify sling kits that were currently being manufactured or no longer produced. The websites of different manufacturers were examined in order to obtain specific product names and descriptions. After the sling systems were identified, a literature search of peer-reviewed articles in PubMed, Google Scholar, and the Cochrane Library was performed by using these key words: 'TVT sling systems,' 'TVT sling comparison,' 'retropubic sling comparison,' 'retropubic sling systems' and NOT 'transobturator,' 'suburethral sling and MAUDE database.' The names of the following sling kits were also searched in the previously referenced databases: American Medical Systems SPARC, American Medical Systems RetroArc Retropubic Sling System, Bard Align, Bard Pelvilace, Bard Uretex, Boston Scientific Advantage, Boston Scientific Lynx, Boston Scientific ProtoGen, Caldera Desara Sling System, Coloplast Supris, Gynecare TVT, Gynecare TVT Secur, Gynecare Prolift, Gynecare Prosisma, and Mentor ObTape. The search was limited to studies in English that were published between the period after January 1995 and the time of this writing. Secondary references listed in the original citations revealed additional studies to be used in this review. In addition, the US Food and Drug Administration (FDA) Manufacturer and User Facility Device Experience Database (MAUDE) was used to identify potential adverse events associated with each sling kit. The FDA's 510(k) Database was used to search for required premarketing submissions made to the FDA to demonstrate that a proposed device to be marketed is as safe and effective as a legally marketed device.

\section{Participants}

Participants of interest were women in a medical setting who were seeking surgical relief for SUI.

\section{Outcomes}

The primary outcomes of interest were as follows: 1) public acceptability of the tension-free retropubic sling procedure to treat SUI; 2) tension-free retropubic sling kits most frequently being used in practice today; 3 ) measures of safety of the different sling kits used in practice, namely adverse effects and complications such as persistent or worsening SUI, development of urinary tract infection, de novo overactive bladder symptoms, lower urinary tract symptoms, retention, sling erosion and extrusion, bladder perforation, urinary retention, bleeding, pelvic pain, and dyspareunia; and 4) positive subjective and objective treatment outcomes, such as relief from SUI and patient satisfaction.

\section{Measures}

In comparison studies of different sling kits, treatment outcomes were measured using the following assessment instruments: 1) the Incontinence Impact Questionnaire (IIQ), which assesses the impact of UI on activities and emotions in women; ${ }^{16}$ 2) the Urogenital Distress Inventory, which complements the IIQ and measures the severity of symptom distress of UI on daily life; ${ }^{16}$ and 3) the Patient Global Impression of Improvement, a measure of overall improvement of UI symptoms. ${ }^{17}$ In addition to the IIQ, the Urogenital Distress Inventory, and the Patient Global Impression of Improvement, researchers also performed stress provocation tests, pad tests, gynecological examinations, and urodynamic investigations in order to evaluate the postoperative effects of the retropubic sling procedure. Subjective outcomes were determined by patient self-report responses to one of the validated questionnaires or instruments listed previously. Objective outcomes were determined by a negative cough or pad test. ${ }^{18}$

\section{Results}

In the scientific, peer-reviewed literature excluding the consumer-reported negative side effects in the MAUDE database, there are a total of 38 studies that have examined side effects, outcomes, and patient acceptability of eight tension-free retropubic sling kits. Table 1 contains currently available sling kits. The studies include a total of 7,083 women who sought treatment for SUI between 1995 and 2014. On October 20, 2008, the FDA issued a Public Health Notification regarding the complications associated with surgical mesh being used to treat SUI. ${ }^{19}$ The FDA Notification was based on numerous patient reports of adverse events that were associated with surgical mesh; these include vaginal extrusion, erosion, infection, pain, dyspareunia, lower 
urinary tract symptoms, recurrence of incontinence, urinary retention, and blood vessel injury. ${ }^{19}$ Some of the side effects resulted in a significant decrease in a patient's quality of life. ${ }^{19}$ The FDA reported that risk factors for patients who are more susceptible to complications are unknown but may include the health of the patient, the condition of the vaginal epithelium, previous vaginal surgeries, the mesh material and shape, the surgical technique used, and the accompanying procedures performed. In response to the FDA's report, several sling kit manufacturers withdrew their sling kits from the market. Table 2 lists discontinued sling kits. Because transvaginal retropubic suburethral sling procedures remain a common treatment of SUI, many manufacturers continue to produce sling kits. A description of outcomes for each kit is provided in the next section. A summary of the most commonly cited adverse effects associated with each sling kit is provided in Table 3 . The literature review revealed only three sling kits in which treatment outcomes were evaluated. Objective and subjective treatment outcomes were measured in the Gynecare TVT, the SPARC, and the Lynx. The results are reported in Table 4.

\section{Gynecare TVT}

The Gynecare TVT sling kit was examined in the majority of studies and was also reported in 2007 as being the most widely used retropubic sling system. ${ }^{20}$ There are 20 reports on the Gynecare TVT alone and nine reports comparing the Gynecare TVT to other slings, including the Align, ${ }^{21}$ the Advantage, ${ }^{22}$ the Lynx, ${ }^{23}$ and the SPARC. ${ }^{24-28}$ Results indicated that $8(0.2 \%)$ to $131(3 \%)$ of 437 women experienced the following side effects immediately resulting from surgery using the Gynecare TVT: bladder perforation (number of patients $[n]=10)$, hematoma $(n=2)$, urinary tract infection $(n=9)$, urinary retention $(n=10)$, de novo overactive bladder symptoms $(n=14)$, voiding dysfunction $(n=10)$, sling erosion $(n=7)$, groin pain $(n=2)$, wound infection $(n=3)$, mixed

Table 2 Discontinued suburethral retropubic sling kits by manufacturer

\begin{tabular}{llll}
\hline $\begin{array}{l}\text { Sling kit } \\
\text { name }\end{array}$ & Manufacturer & $\begin{array}{l}\text { Year } \\
\text { discontinued }\end{array}$ & $\begin{array}{l}\text { Number of } \\
\text { MAUDE* } \\
\text { complaints }\end{array}$ \\
\hline Avaulta Plus & Bard & 2012 & $>500$ \\
Pelvilace & Bard & N/A & 182 \\
Uretex & Bard & N/A & 154 \\
ProteGen & Boston Scientific & 1999 & 19 \\
\hline
\end{tabular}

Notes: Table is based on data from Drugwatch.com. ${ }^{57}$ *The FDA MAUDE database lists reported adverse events associated with each sling kit.

Abbreviations: N/A, not available; FDA, US Food and Drug Administration; MAUDE, Manufacturer and User Facility Device Experience Database. incontinence $(n=1)$, and worsening urge incontinence $(n=1) .{ }^{29}$ In addition, $12.8 \%$ of participants $(n=24)$ reported a positive cough stress test. In another study, $6 \%$ of patients $(n=24)$ suffered from bladder perforation, $4 \%(n=18)$ from postoperative voiding difficulties, and $0.5 \%(n=2)$ from retropubic bleeding that required surgery. ${ }^{30}$ A large scale study of 2,795 women revealed immediate complications that consisted of urinary tract infections in a large percentage of the women $(17 \%, n=475) .{ }^{31}$ Other side effects reported in this study include bladder perforation $(n=75)$ and hematoma $(n=19) .{ }^{31}$ Urinary tract infection, bladder perforation, and hematoma were also symptoms reported in $4.1 \%, 3.8 \%$, and $2.3 \%$ of patients, respectively, in a study of 1,455 women; these appear to be the three most commonly reported symptoms for the TVT procedure. ${ }^{32}$

Medium-term reported outcomes of the Gynecare TVT affected approximately $1 \%$ to $8.3 \%$ of 321 women, and these effects included postoperative voiding difficulties $(n=8)$, vaginal erosion $(n=4)$, subjective persistent mild SUI $(n=16)$, asymptomatic sphincteric incontinence $(n=17)$, asymptomatic pelvic organ prolapse $(n=6)$, recurrent urinary tract infections $(n=6)$, and de novo urge incontinence $(n=25) .{ }^{33,34}$ A study of long-term effects in 271 women revealed that nine women reported having a failed operation, five women reported no change after surgery, and two women reported that symptoms worsened after surgery. ${ }^{35-38}$ In an additional study of 598 women, 17 (2.8\%) women underwent a sling release in which the sling was removed because of subjective reported symptoms and the surgeon's concerns. ${ }^{39}$ Another study revealed that $2.4 \%(n=68)$ women required reoperation because of complications related to the TVT operation. ${ }^{31}$ Additional studies and side effects are listed in Table 3.

Despite the numerous reported negative symptoms, the Gynecare TVT had positive treatment outcomes for the majority of patients. Results of two long-term studies show that of a total of 84 women, between $85 \%$ and $87 \%$ of the patients were cured by the 3 year follow-up, and between $89 \%$ and $98 \%$ of patients improved significantly. ${ }^{36,40}$ Further, objective cure rates ranged from $81.3 \%$ to $91.3 \%$, and subjective ones ranged from $77 \%$ to $92 \%$; the average rates were $86.2 \%$ for objective cures and $86.5 \%$ for subjective cures $(\mathrm{n}=1,578) .^{30,34,35,37,38,41-44}$

\section{SPARC}

There are six studies in the literature on the SPARC alone and five that compare the SPARC to the Gynecare TVT. ${ }^{24-28,45-50}$ In 35 of 390 women $(9.0 \%)$, the reported side effects associated with the SPARC sling kit included the following: bladder 
Table 3 Adverse effects of retropubic sling kits

\begin{tabular}{|c|c|c|c|c|c|c|c|c|c|}
\hline \multirow{2}{*}{$\begin{array}{l}\text { Sling kit name } \\
\text { (name of } \\
\text { company) }\end{array}$} & \multirow[t]{2}{*}{ Study } & \multirow[t]{2}{*}{$\mathbf{N}$} & \multicolumn{7}{|c|}{ Number of patients reporting adverse effects (\% with respect to $\mathbf{N})$} \\
\hline & & & $\begin{array}{l}\text { Persistent } \\
\text { SUI }\end{array}$ & $\begin{array}{l}\text { Worsening } \\
\text { SUI }\end{array}$ & $\begin{array}{l}\text { De novo } \\
\text { overactive } \\
\text { bladder } \\
\text { symptoms }\end{array}$ & Hematoma & UTI & $\begin{array}{l}\text { Intraoperative } \\
\text { bladder } \\
\text { perforation }\end{array}$ & $\begin{array}{l}\text { Vaginal } \\
\text { erosion }\end{array}$ \\
\hline Gynecare TVT & Abouassaly et $\mathrm{a}^{59}$ & 241 & $14(5.8 \%)$ & & $33(13.6 \%)$ & $4(1.9 \%)$ & $25(\mathrm{II} .8 \%)$ & $14(5.8 \%)$ & $2(0.8 \%)$ \\
\hline \multirow[t]{14}{*}{ (Ethicon) } & Hong et $\mathrm{al}^{42}$ & 375 & & & $12(3.2 \%)$ & $4(1.1 \%)$ & $5(1.3 \%)$ & 35 (9.3\%) & \\
\hline & Karram et $\mathrm{al}^{58}$ & 350 & $6(1.7 \%)$ & & & $6(1.7 \%)$ & $38(10.9 \%)$ & $17(4.9 \%)$ & $3(0.9 \%)$ \\
\hline & Klutke et al ${ }^{39}$ & 598 & I (0.1\%) & & & & & & \\
\hline & Kuuva and Nilsson ${ }^{32}$ & $\mathrm{I}, 455$ & & & II (0.8\%) & $34(2.3 \%)$ & 59 (4.I\%) & $56(3.8 \%)$ & \\
\hline & Levin et $\mathrm{a}^{33}$ & 241 & $16(6.6 \%)$ & & $20(8.3 \%)$ & & & & $4(1.7 \%)$ \\
\hline & Meschia et $\mathrm{al}^{30}$ & 404 & & & & & & 24 (5.9\%) & \\
\hline & Nilsson et $\mathrm{al}^{34}$ & 80 & & & $5(6.3 \%)$ & & $6(7.5 \%)$ & & \\
\hline & Nilsson et $\mathrm{al}^{35}$ & 101 & & $2(2.0 \%)$ & & & & & \\
\hline & Paick et al ${ }^{44}$ & 274 & & & $3(1.7 \%)$ & & I (0.4\%) & 13 (4.7\%) & \\
\hline & Tamussino et $\mathrm{a}^{31}$ & 2,795 & & & & $19(0.7 \%)$ & $475(17 \%)$ & 75 (2.7\%) & \\
\hline & Tincello et $\mathrm{al}^{29}$ & 437 & & I (0.2\%) & 15 (3.4\%) & $2(0.5 \%)$ & $9(2.1 \%)$ & $10(2.3 \%)$ & $7(1.6 \%)$ \\
\hline & Tsivian et a $\mathrm{a}^{43}$ & 55 & & & & & & $3(5.8 \%)$ & $2(3.8 \%)$ \\
\hline & Tsivian et a ${ }^{61}$ & 200 & & & & & $9(4.5 \%)$ & I (0.5\%) & $4(2.0 \%)$ \\
\hline & Wang ${ }^{60}$ & 600 & & & & & & $5(0.8 \%)$ & \\
\hline SPARC (American & Deval et $\mathrm{a}^{45}$ & 104 & & & $12(11.5 \%)$ & & & & \\
\hline \multirow[t]{3}{*}{ Medical Systems) } & Heidler et $\mathrm{al}^{47}$ & 46 & & & $5(10.9 \%)$ & & & & \\
\hline & Kobashi and Govier ${ }^{50}$ & 150 & & & & $4(2.9 \%)$ & & & \\
\hline & Siddiqui et $\mathrm{al}^{46}$ & 100 & & & & I (I.0\%) & & I (I.0\%) & $\mathrm{I}(\mathrm{I} .0 \%)$ \\
\hline Advantage (Boston & Basu and Duckett ${ }^{52}$ & 33 & I (3.0\%) & & & & & & \\
\hline Scientific) & Renganathan et $\mathrm{al}^{51}$ & 70 & $4(5.7 \%)$ & & $2(2.9 \%)$ & & & & \\
\hline Lynx (Boston & Noblett et $\mathrm{al}^{53}$ & 102 & & & $6(5.9 \%)$ & & & & $5(4.9 \%)$ \\
\hline
\end{tabular}

Abbreviations: N, total number of patients in study; SUI, stress urinary incontinence; UTI, urinary tract infection.

perforation $(n=1)$, vaginal erosion $(n=1)$, hematoma $(n=5)$, urinary retention $(n=11)$, and de novo overactive bladder symptoms and urgency symptoms $(n=17) .{ }^{45-47,50}$ However, these symptoms occurred in less than $12 \%$ of cases, and more severe symptoms, such as vaginal erosion or bladder perforation, occurred in $1 \%$ of cases or less.

Treatment outcomes of the SPARC were generally positive. Objective and subjective cure rates ranged from $76 \%$ to $90.4 \%(n=216)$ and $52 \%$ to $75 \%(n=176)$, respectively, with an average of $83.6 \%$ for the objective cure rate and $66.4 \%$ for the subjective cure rate $(\mathrm{n}=253) .{ }^{45,47,48}$ Studies revealed that, on average, $90.9 \%(n=491)$ of patients would recommend the SPARC to a friend. ${ }^{47-49}$

\section{Advantage}

There are two studies on the Advantage alone and one report in which the Advantage and the Gynecare TVT are compared. 22,51,52 Studies indicate that $3 \%$ to $7 \%$ of users of the Advantage have experienced persistent SUI $(n=5)$, de novo overactive bladder symptoms $(n=2)$, or SUI during urodynamic testing $(n=2) .{ }^{51,52}$ Currently, there are no existing data on positive treatment outcomes or patient satisfaction ratings for the Advantage.

\section{Lynx}

To date, there is only one study in which the Lynx has been examined alone, and another study in which the Lynx has been compared to the Gynecare TVT. ${ }^{23,53}$ Reported side effects of the Lynx included vaginal extrusion $(n=5)$ and de novo overactive bladder symptoms and urge incontinence symptoms $(n=6)$ that were experienced by less than $6 \%$ of 103 patients. ${ }^{53}$ The reported failure rate associated with the Lynx was $9.8 \%$ $(n=10) .{ }^{53}$ Despite the negative side effects and failure rate, the reported success rate for the Lynx was $90.2 \%(n=92){ }^{53}$

\section{RetroArc Retropubic Sling System, Desara, and Coloplast Supris}

There are no existing studies in which the RetroArc Retropubic Sling System, the Desara, and the Supris (Coloplast, Minneapolis, MN, USA) sling kits have been examined. However, the RetroArc used the American Medical Systems sling that had been tested in previous studies. ${ }^{24-28,45-50}$

\section{Comparison studies}

Comparison studies revealed that there are few significant differences between the Gynecare TVT and its competitors. ${ }^{21-28}$ 
Table 4 Positive and negative treatment outcomes of retropubic sling kits

\begin{tabular}{|c|c|c|c|c|c|c|c|}
\hline \multirow[t]{2}{*}{ Sling kit name } & \multirow[t]{2}{*}{ Study } & \multirow[t]{2}{*}{$\mathbf{N}_{\mathbf{T}}$} & \multicolumn{3}{|c|}{$\begin{array}{l}N \text { with positive treatment outcomes } \\
\text { (\% with respect to } N_{T} \text { ) }\end{array}$} & \multicolumn{2}{|c|}{$\begin{array}{l}\mathrm{N} \text { with negative } \\
\text { treatment outcomes } \\
\left(\% \text { with respect to } \mathrm{N}_{\mathrm{T}} \text { ) }\right.\end{array}$} \\
\hline & & & $\begin{array}{l}\text { Objective } \\
\text { cure* }\end{array}$ & $\begin{array}{l}\text { Subjective } \\
\text { cure* }\end{array}$ & $\begin{array}{l}\text { Recommend } \\
\text { to a friend }\end{array}$ & $\begin{array}{l}\text { Failed } \\
\text { operation** }\end{array}$ & $\begin{array}{l}\text { No } \\
\text { change }\end{array}$ \\
\hline Gynecare & Hong et $\mathrm{a}^{42}$ & 375 & $335(89.3 \%)$ & 34 I (9I.0\%) & & & \\
\hline \multirow[t]{12}{*}{ TVT (Ethicon) } & Klutke et $\mathrm{al}^{39}$ & 598 & & & & $17(2.8 \%)$ & \\
\hline & Meschia et $\mathrm{al}^{30}$ & 404 & $364(90.1 \%)$ & 377 (93.3\%) & & & \\
\hline & Nilsson et $\mathrm{al}^{34}$ & 80 & $65(81.3 \%)$ & $65(81.3 \%)$ & & & \\
\hline & Nilsson et $\mathrm{al}^{35}$ & 90 & $42 / 46$ (91.3\%) & $48 / 55(87.3 \%)$ & & & $5(5.0 \%)$ \\
\hline & Nilsson et $\mathrm{al}^{37}$ & 85 & $72(84.7 \%)$ & $72(84.7 \%)$ & & $4(4.7 \%)$ & \\
\hline & Nilsson et $\mathrm{al}^{41}$ & 69 & 55 (79.7\%) & $53(76.8 \%)$ & & & \\
\hline & Olsson and Kroon ${ }^{38}$ & 51 & $46(90.2 \%)$ & $46(90.2 \%)$ & & $2(3.9 \%)$ & \\
\hline & Paick et $\mathrm{al}^{44}$ & 274 & 249 (90.9\%) & 249 (90.9\%) & & & \\
\hline & Rezapour and Ulmsten ${ }^{36}$ & 34 & $28(82.4 \%)$ & $28(82.4 \%)$ & & $3(8.8 \%)$ & \\
\hline & Tamussino et $\mathrm{a}^{31}$ & 2,795 & & & & $68(2.4 \%)$ & \\
\hline & Tsivian et $\mathrm{al}^{43}$ & 55 & $41 / 52(78.9 \%)$ & $4 \mathrm{I} / 52$ (78.9\%) & & & \\
\hline & Ulmsten et $\mathrm{al}^{40}$ & 50 & $43(86 \%)$ & $43(86 \%)$ & & & \\
\hline SPARC & Deval et $\mathrm{al}^{45}$ & 104 & 94 (90.4\%) & $75(72.1 \%)$ & & & \\
\hline (American & Heidler et $\mathrm{al}^{47}$ & 46 & $35(76.0 \%)$ & $24(52.2 \%)$ & 45 (97.8\%) & & \\
\hline Medical & Hodroff et $\mathrm{al}^{49}$ & 445 & & & $374(84.0 \%)$ & & \\
\hline Systems) & Primus ${ }^{48}$ & 103 & 87 (84.5\%) & 77 (74.8\%) & & & \\
\hline Lynx (Boston & Noblett et $\mathrm{al}^{53}$ & 102 & 92 (90.2\%) & $92(90.2 \%)$ & & $10(9.8 \%)$ & \\
\hline Scientific) & & & & & & & \\
\hline
\end{tabular}

Notes: *Objective outcomes were determined by a negative cough, stress test in standing position, or pad test. Subjective outcomes were determined by patient selfreported responses to a validated questionnaire such as the Incontinence Impact Questionnaire, the Urogenital Distress Inventory, or the Patient Global Impression of Improvement. **Criteria for a failed operation vary by study, but they include slight or no improvement in SUI symptoms and low patient satisfaction. Nilsson et al ${ }^{34}$ and Tsivian et al ${ }^{43}$ list a different number of participants $\left(\mathrm{N}_{\mathrm{T}}\right)$ because original studies began with 90 and 55 women respectively; however, at follow up, not all women could be reached so the number of participants that were able to report was reduced.

Abbreviations: $\mathrm{N}_{\mathrm{T}}$, total number of patients in study; $\mathrm{N}$, number of patients; SUI, stress urinary incontinence.

When compared to the Align, the Gynecare TVT was not significantly different regarding urethrolysis in order to treat obstructive voiding symptoms. ${ }^{21}$ When comparing the Gynecare TVT to the Advantage, researchers found no significant differences in side effects such as bladder injury, voiding difficulty, and de novo urgency. ${ }^{22}$ In terms of outcomes, the same study also revealed no differences in persistent subjective SUI between the Gynecare TVT and the Advantage. The study comparing the Gynecare TVT to the Lynx revealed that postoperative voiding dysfunction was more common in the Gynecare TVT $(P<0.001) .{ }^{23}$ However, there was no difference between the subjective cure rates of the two sling kits.

In several studies, researchers examined the Gynecare TVT sling kit in comparison to the SPARC. Results of one study revealed that symptoms of weak urinary stream, one of nine lower urinary tract symptoms, was more closely associated with the Gynecare TVT than with the SPARC $(P<0.01) .{ }^{24}$ However, there was no significant difference between the two systems for the remaining eight lower urinary tract symptoms. Another comparison study revealed that users of the SPARC were more likely to experience acute urinary retention than the users of the Gynecare TVT $(P<0.01) .{ }^{26}$ Additionally, researchers of the same study found that the Gynecare TVT had a higher subjective cure rate than did the SPARC $(P<0.01)$. In the remainder of the comparison studies, no differences were found between the Gynecare TVT and the SPARC for objective and subjective cure rates, postoperative complications, or postoperative incontinence. ${ }^{25,27,28}$ In summary, a review of comparison studies revealed that the Gynecare TVT does not differ greatly from the Align, Advantage, Lynx, and SPARC in terms of treatment outcomes or side effects.

In conclusion, there are insufficient data to determine which sling kit has better treatment outcomes compared to others. Statistical analyses to compare kits were not possible due to a lack of data on several kits, differential measures of outcomes, and disproportionate sample sizes in the studies examining the different kits. However, the most commonly researched sling kits are the Gynecare TVT and SPARC systems. Although side effects slightly vary with each kit, the Gynecare TVT and the SPARC have similar textile properties, low risks of side effects, positive treatment outcomes, and high patient acceptability.

\section{Discussion}

The aims of the current review were to examine patient and physician acceptability of the retropubic sling procedure as 
a treatment for SUI and to investigate the currently available retropubic sling kits in order to determine which sling kit may be the most efficient and provides the best treatment outcomes. Although there are many companies manufacturing retropubic sling kits, there are eight sling kits considered dominant in the market today: SPARC, RetroArc, Align, Advantage, Lynx, Desara, Supris, and Gynecare TVT.

A general web search and a search of the FDA MAUDE database revealed four sling kits that have been discontinued: Avaulta Plus, Uretex, Pelvilace, and ProteGen. Table 2 contains information regarding the year that the slings were discontinued as well as the number of reports filed in the MAUDE database for each sling. It is important to note that researchers found a large discrepancy between complications listed in MAUDE, a public database for reporting device failure, and the published literature, which is reported by researchers, for instance, on surgical complications. ${ }^{54}$ The MAUDE database has an estimated four times as many reported complications than does the literature. ${ }^{54}$ Researchers hypothesize that surgeons may be underreporting complications because of experience, referral patterns, and a failure to diagnose.$^{54}$ Unfortunately, there is a lack of a national registry in which both clinicians and the public report complications associated with slings. The discrepancies in reported complications make it difficult to determine specific reasons for a product's removal from the market. Additionally, because of the varying number of consumer complaints for each of the slings, it is unlikely that the products were discontinued solely based on the volume of complaints. It is probable that legal actions against the manufacturers also heavily influenced the removal of these products from the market.

The Gynecare TVT and the SPARC have been examined in the majority of studies. The results of these studies indicate that the two slings vary slightly in terms of reported side effects but are highly similar in terms of efficacy and positive patient outcomes. ${ }^{24-28}$ Studies revealed that the Gynecare TVT and the SPARC had similar outcomes in terms of lower urinary tract symptoms, bladder perforation, blood loss, hesitancy, urgency, postoperative incontinence, acute urinary retention, and objective cure rates. ${ }^{24-28}$

The Gynecare TVT has also been compared to the Advantage, the Align, and the Lynx. ${ }^{21-23}$ Results of the comparison studies show that there were no significant differences in terms of side effects or subjective patient outcomes across the different kits, although users of the Gynecare TVT did report a higher likelihood of postoperative voiding dysfunction than did users of the Lynx ${ }^{23}$ Reported studies on the Advantage, the Align, and the Lynx indicate comparable outcomes to the Gynecare TVT but are limited and hence make it difficult to draw any conclusions on efficacy. Outcomes on the RetroArc, the Desara, and the Supris sling kits have not yet been reported. It is likely that patient factors, such as the patient's anatomy and prior surgeries, also influence outcomes of each sling procedure. However, most studies have not controlled for pre-existing patient conditions when comparing outcomes of the different sling procedures. More research is needed to determine which sling may be superior in terms of safety and efficiency for patients with certain pre-existing medical conditions.

Results of a comprehensive literature search revealed 38 studies that reported on retropubic sling kits during the last 19 years. Of note, six of the 38 research studies were supported by the industry. Ethicon claimed interest in all six studies, and American Medical Systems had interest in three of the six studies. ${ }^{18,22,24,29,39,52}$ Coloplast and Boston Scientific each declared interest in one of the research studies. ${ }^{18,52}$ Given that Ethicon is the first manufacturer of the retropubic sling kit and the company is a subsidiary of Johnson and Johnson, it is not surprising that the company has strong research support. It remains speculative if other manufacturers may advance in research and have the volume of support equal to Ethicon. In other words, there is insufficient research on each sling kit to significantly determine which sling is superior in terms of patient acceptability, side effects, and treatment outcomes. Given the lack of supporting literature for the efficacy of one particular brand of sling kit over another, researchers may wish to conduct further testing of each kit in comparison to others to help surgeons decide which kit may be most beneficial for their patients. However, for now, the particular sling kit used in surgery is best determined by the medical provider's preference, training, and past experience.

One limitation of the current review is that the manufacturer's websites did not provide pricing for each sling kit. We contacted each manufacturer to obtain prices by telephone; however, we were informed that the variations in cost depend on several factors, including the location and the type of institution to which the products are being sold, the volume of products purchased, and the terms of the contract that the manufacturer has with the buyer. Therefore, because of the inability to obtain consistent prices for the sling kits, we were not able to include cost as a factor in our analysis. Given the rising costs of health care, it is likely that medical providers will take cost into consideration when selecting which sling kit procedure to perform on their patients. Another limitation is that the manufacturer's websites did not provide the reasons, such as quality of the synthetic material, the supporting material, the costs, or the legal issues, for the withdrawal of the sling kits (Table 2). 
Additionally, this review focused solely on retropubic sling kits. Several larger studies have been conducted to compare TVT and TOT sling kits. ${ }^{12,18,55}$ It may be of interest to conduct a similar review to focus on TOT sling kit systems. Despite these limitations, the current study provides insight into common side effects and outcomes associated with each sling kit brand, and this review may assist medical providers in making appropriate treatment choices for patients.

In summary, there are currently eight retropubic sling kits being manufactured to treat SUI. Since 1995, the Gynecare TVT has been the most widely used and has had the most references found in the literature. ${ }^{9,20}$ The SPARC has a similar structure and similar treatment outcomes as the Gynecare TVT; however, the two slings vary with regard to side effects. ${ }^{24-28}$ Users of the Gynecare TVT have reported greater instances of a decreased urinary stream than have users of the SPARC, whereas users of the SPARC have reported more instances of acute urinary retention than have users of Gynecare TVT. The two kits have good objective and subjective cure rates ranging from $77 \%$ to $92 \%$ for the Gynecare TVT and from $52 \%$ to $90.4 \%$ for the SPARC.

Each reviewed sling kit has positive and negative outcomes. Although the Gynecare TVT is the most studied and has the longest history, it is not necessarily the best retropubic sling system to treat SUI. More comprehensive research is needed to compare specific brands of sling kits, but the information provided in this review could be used to help health care providers make more informed decisions regarding patient care.

\section{Conclusion}

In this review, we examined side effects, treatment outcomes, and patient acceptability of suburethral retropubic slings, which are currently the gold standard for surgical treatment of SUI. An extensive review of the literature revealed that despite a 2008 FDA warning about complications linked to mesh material used in certain retropubic slings, the retropubic tension-free suburethral sling kit procedure is still considered to be the first-line treatment for SUI. ${ }^{10}$ The Gynecare TVT has been the most widely used and best researched procedure since its invention in 1995. Given that there is a disproportionate amount of literature on each type of sling kit, it is difficult to make valid comparisons between the different brands. Therefore, at this time, the decision regarding which sling system to use depends on the surgeon's past experience, training, and preference. Patients are not being provided with options regarding the sling system used to treat their incontinence symptoms. Further research in this area, including a cost analysis, is encouraged in order to provide patients and physicians with more information regarding which sling kit may be best suited for each individual.

\section{Disclosure}

The authors of this manuscript report no conflicts of interest in this work.

\section{References}

1. Abrams P, Cardozo L, Fall M, et al. The standardisation of terminology of lower urinary tract function: report from the Standardisation Subcommittee of the International Continence Society. Neurourol Urodyn. 2002;21(2):167-178.

2. Yip SK, Chan A, Pang S, et al. The impact of urodynamic stress incontinence and detrusor overactivity on marital relationship and sexual function. Am J Obstet Gynecol. 2003;188(5):1244-1248.

3. Luber KM. The definition, prevalence, and risk factors for stress urinary incontinence. Rev Urol. 2004;6(Suppl 3):S3-S9.

4. Haylen BT, de Ridder D, Freeman RM, et al. An International Urogynecological Association (IUGA)/International Continence Society (ICS) joint report on the terminology for female pelvic floor dysfunction. Neurourol Urodyn. 2010;29(1):4-20.

5. Reynolds WS, Dmochowski RR, Penson DF. Epidemiology of stress urinary incontinence in women. Curr Urol Rep. 2011;12(5):370-376.

6. Fritel X, Fauconnier A, Bader G, et al. Diagnosis and management of adult female stress urinary incontinence: guidelines for clinical practice from the French College of Gynaecologists and Obstetricians. Eur J Obstet Gynecol Reprod Biol. 2010;151(1):14-19.

7. Mainprize TC, Drutz HP. The Marshall-Marchetti-Krantz procedure: a critical review. Obstet Gynecol Surv. 1988;43(12):724-729.

8. Holschneider CH, Solh S, Lebherz TB, Montz FJ. The modified Pereyra procedure in recurrent stress urinary incontinence: a 15 -year review. Obstet Gynecol. 1994;83(4):573-578.

9. Ulmsten U, Henriksson L, Johnson P, Varhos G. An ambulatory surgical procedure under local anesthesia for treatment of female urinary incontinence. Int Urogynecol J Pelvic Floor Dysfunct. 1996;7(2):81-86.

10. Harding CK, Thorpe AC. Surgical treatment for stress urinary incontinence. Int J Urol. 2008;15(1):27-34

11. Cosson M, Debodinance P, Boukerrou M, et al. Mechanical properties of synthetic implants used in the repair of prolapse and urinary incontinence in women: which is the ideal material? Int Urogynecol J. 2003; 14(3);169-178.

12. Wu MP, Huang KH. Tension-free midurethral sling surgeries for stress urinary incontinence. Incont Pelvic Floor Dysfunct. 2008;2(2):53-60.

13. Moalli PA, Papas N, Menefee S, Albo M, Meyn L, Abramowitch SD. Tensile properties of five commonly used mid-urethral slings relative to the TVT ${ }^{\mathrm{TM}}$. Int Urogynecol J. 2008;19(5):655-663.

14. Ostergard DR. Polypropylene vaginal mesh grafts in gynecology. Obstet Gynecol. 2010;116(4):962-966.

15. Morehead JM, Holt GR. Soft-tissue response to synthetic biomaterials. Otolaryngol Clin North Am. 1994;27(1):195-201.

16. Harvey MA, Kristjansson B, Griffith D, Versi E. The Incontinence Impact Questionnaire and the Urogenital Distress Inventory: A revisit of their validity in women without a urodynamic diagnosis. Am J Obstet Gynecol. 2001;185(1):25-30.

17. Yalcin I, Bump RC. Validation of two global impression questionnaires for incontinence. Am J Obstet Gynecol. 2003;189(1):98-101.

18. Fong ED, Nitti VW. Review article: Mid-urethral synthetic slings for female stress urinary incontinence. BJU Int. 2010;106(5):596-608.

19. Serious complications associated with transvaginal placement of surgical mesh in repair of pelvic organ prolapse and stress urinary incontinence [webpage on the Internet]. Silver Spring: US Food and Drug Administration; 2008. Available from: http://www.fda.gov/ MedicalDevices/safety/AlertsandNotices/PublicHealthNotifications/ ucm061976.htm. Accessed September 29, 2014. 
20. Andonian S, St-Denis B, Lemieux MC, Corcos J. Prospective clinical trial comparing Obtape and DUPS to TVT: one-year safety and efficacy results. Eur Urol. 2007;52(1):245-252.

21. Kawasaki A, Edenfield AL, Visco AG, Wu JM, Westreich D, Siddiqui NY. Comparing the risk of urethrolysis for the treatment of voiding dysfunction between two retropubic mesh slings: a case-control study. Int Urogynecol J. 2013;24(4):589-594.

22. Lim YN, Dwyer P, Muller R, Rosamilia A, Lee J, Stav K. Do the Advantage slings work as well as the tension-free vaginal tapes? Int Urogynecol J. 2010;21(9):1157-1162.

23. Agarwala N, Griffin J. A Randomized Comparison of GYNECARE TVT and Boston Scientific Lynx Suprapubis Mid-Urethral Sling. Obstet Gynecol. 2006;107(4):46S-47S.

24. Dietz HP, Foote AJ, Mak HLJ, Wilson PD. TVT and Sparc suburethral slings: a case-control series. Int Urogynecol J. 2004;15(2):129-131.

25. Andonian S, Chen T, St-Denis B, Corcos J. Randomized clinical trial comparing suprapubic arch sling (SPARC) and tension-free vaginal tape (TVT): One-year results. Eur Urol. 2005;47(4):537-541.

26. Lord HE, Taylor JD, Finn JC, et al. A randomized controlled equivalence trial of short-term complications and efficacy of tension-free vaginal tape and suprapubic urethral support sling for treating stress incontinence. BJU Int. 2006;98(2):367-376.

27. Tseng LH, Wang AC, Lin YH, Li SJ, Ko YJ. Randomized comparison of the suprapubic arc sling procedure vs tension-free vaginal taping for stress incontinent women. Int Urogynecol J. 2005;16(3):230-235.

28. Paick JS, Oh SJ, Kim SW, Ku JH. Tension-free vaginal tape, suprapubic arc sling, and transobturator tape in the treatment of mixed urinary incontinence in women. Int Urogynecol J. 2008;19(1):123-129.

29. Tincello DG, Botha T, Grier D, et al. The TVT Worldwide Observational Registry for Long-Term Data: safety and efficacy of suburethral sling insertion approaches for stress urinary incontinence in women. J Urol. 2011;186(6):2310-2315.

30. Meschia M, Pifarotti P, Bernasconi F, et al. Tension-free vaginal tape: Analysis of outcomes and complications in 404 stress incontinent women. Int Urogynecol J. 2001;12(2):S24-S27.

31. Tamussino KF, Hanzal E, Kölle D, Ralph G, Riss PA; Austrian Urogynecology Working Group. Tension-free vaginal tape operation: results of the Austrian registry. Obstet Gynecol. 2001;98(5 Pt 1):732-736.

32. Kuuva N, Nilsson CG. A nationwide analysis of complications associated with the tension-free vaginal tape (TVT) procedure. Acta Obstet Gynecol Scand. 2002;81(1):72-77.

33. Levin I, Groutz A, Gold R, Pauzner D, Lessing JB, Gordon D. Surgical complications and medium-term outcome results of tension-free vaginal tape: A prospective study of 313 consecutive patients. Neurourol Urodyn. 2004;23(1):7-9.

34. Nilsson CG, Falconer C, Rezapour M. Seven-year follow-up of the tension-free vaginal tape procedure for treatment of urinary incontinence. Obstet Gynecol. 2004;104(6):1259-1262.

35. Nilsson CG, Palva K, Aarnio R, Morcos E, Falconer C. Seventeen years' follow-up of the tension-free vaginal tape procedure for female stress urinary incontinence. Int Urogynecol J. 2013;24(8):1265-1269.

36. Rezapour M, Ulmsten U. Tension-free vaginal tape (TVT) in women with recurrent stress urinary incontinence - a long-term follow up. Int Urogynecol J. 2001;12(2):S9-S11.

37. Nilsson CG, Kuuva N, Falconer C, Rezapour M, Ulmsten U. Long-term results of the tension-free vaginal tape (TVT) procedure for surgical treatment of female stress urinary incontinence. Int Urogynecol J. 2001; 12(2):S5-S8.

38. Olsson I, Kroon UB. A three-year postoperative evaluation of tensionfree vaginal tape. Gynecol Obstet Invest. 1999;48(4):267-269.

39. Klutke C, Siegel S, Carlin B, Paszkiewicz E, Kirkemo A, Klutke J. Urinary retention after tension-free vaginal tape procedure: incidence and treatment. Urology. 2001;58(5):697-701.

40. Ulmsten U, Johnson P, Rezapour M. A three-year follow up of tension free vaginal tape for surgical treatment of female stress urinary incontinence. Br J Obstet Gynaecol. 1999;106(4):345-350.
41. Nilsson CG, Palva K, Rezapour M, Falconer C. Eleven years prospective follow-up of the tension-free vaginal tape procedure for treatment of stress urinary incontinence. Int Urogynecol J. 2008; 19(8):1043-1047.

42. Hong B, Park S, Kim HS, Choo MS. Factors predictive of urinary retention after a tension-free vaginal tape procedure for female stress urinary incontinence. J Urol. 2003;170(3):852-856.

43. Tsivian A, Mogutin B, Kessler O, Korczak D, Levin S, Sidi AA. Tensionfree vaginal tape procedure for the treatment of female stress urinary incontinence: long-term results. J Urol. 2004;172(3):998-1000.

44. Paick JS1, Ku JH, Shin JW, Oh SJ, Kim SW. Complications associated with the tension-free vaginal tape procedure: the Korean experience. Int Urogynecol J Pelvic Floor Dysfunct. 2005;16(3):215-219.

45. Deval B, Levardon M, Samain E, et al. A French multicenter clinical trial of SPARC for stress urinary incontinence. Eur Urol. 2003; 44(2):254-259.

46. Siddiqui K, Raj H, Flynn RJ, Grainger R, Thornhill JA. Minimally invasive treatment of female stress urinary incontinence: 100 cases using SPARC sling. Ir J Med Sci. 2008;177(1):39-42.

47. Heidler S, Ofner-Kopeinig P, Puchwein E, Pummer K, Primus G. The suprapubic arch sling procedure for treatment of stress urinary incontinence: a 5-year retrospective study. Eur Urol. 2010;57(5):897-901.

48. Primus G. One year follow-up on the SPARC sling system for the treatment of female urodynamic stress incontinence. Int J Urol. 2006; 13(11):1410-1414.

49. Hodroff MA, Sutherland SE, Kesha JB, Siegel SW. Treatment of stress incontinence with the SPARC sling: Intraoperative and early complications of 445 patients. Urology. 2005;66(4):760-762.

50. Kobashi KC, Govier FE. Perioperative complications: the first 140 polypropylene pubovaginal slings. J Urol. 2003;170(5):1918-1921.

51. Renganathan A, Basu M, Duckett J. A series of Advantage suburethral slings. J Obstet Gynaecol. 2011;31(6):521-523.

52. Basu M, Duckett J. Three-year results from a randomised trial of a retropubic mid-urethral sling versus the Miniarc single incision sling for stress urinary incontinence. Int Urogynecol J. 2013;24(12):2059-2064.

53. Noblett KL, Shen B, Lane FL. Lynx ${ }^{\circledR}$ midurethral sling system: A 1-year prospective study on efficacy and safety. Int Urogynecol J. 2008;19(9):1217-1221.

54. Deng DY, Rutman M, Raz S, Rodriguez LV. Presentation and management of major complications of midurethral slings: Are complications under-reported? Neurourol Urodyn. 2007;26(1):46-52.

55. Schulz JA, Chan MC, Farrell SA. Midurethral minimally invasive sling procedures for stress urinary incontinence. J Obstet Gynaecol Can. 2008;30(8):728-740.

56. Shippey SH, Green IC, Quiroz LH, Handa VL, Gutman RE. Midurethral sling outcomes: Tension-free vaginal tape versus Pelvilace. Int Urogynecol J. 2008;19(9):1199-1204.

57. Transvaginal Mesh Recall [webpage on Internet]. Orlando: Drugwatch. com; 2014. Available from: http://www.drugwatch.com/transvaginalmesh/recall.php. Accessed September 30, 2014.

58. Karram MM, Segal JL, Vassallo BJ, Kleeman SD. Complications and untoward effects of the tension-free vaginal tape procedure. Obstet Gynecol. 2003;101(5 Pt 1):929-932.

59. Abouassaly R, Steinberg JR, Lemieux M, et al. Complications of tension-free vaginal tape surgery: a multi-institutional review. $B J U$ Int. 2004;94(1):110-113.

60. Wang AC. The techniques of trocar insertion and intraoperative urethrocystoscopy in tension-free vaginal taping: an experience of 600 cases. Acta Obstet Gynecol Scand. 2004;83(3):293-298.

61. Tsivian A, Kessler O, Mogutin B, et al. Tape related complications of the tension-free vaginal tape procedure. J Urol. 2004;171(2 Pt 1): $762-764$. 
International Journal of Women's Health

Dovepress

\section{Publish your work in this journal}

The International Journal of Women's Health is an international, peerreviewed open-access journal publishing original research, reports, editorials, reviews and commentaries on all aspects of women's healthcare including gynecology, obstetrics, and breast cancer. The manuscript management system is completely online and includes

Submit your manuscript here: http://www.dovepress.com/international-journal-of-womens-health-journa a very quick and fair peer-review system, which is all easy to use. Visit http://www.dovepress.com/testimonials.php to read real quotes from published authors. 